\title{
Carboplatin: molecular mechanisms of action associated with chemoresistance
}

\author{
Graziele Fonseca de Sousa, Samarina Rodrigues Wlodarczyk, Gisele Monteiro* \\ Department of Biochemical and Pharmaceutical Technology, Faculty of Pharmaceutical Sciences, University of São Paulo, \\ São Paulo, SP, Brazil
}

\begin{abstract}
Carboplatin is a derivative of cisplatin; it has a similar mechanism of action, but differs in terms of structure and toxicity. It was approved by the FDA in the 1980s and since then it has been widely used in the treatment of several tumor types. This agent is characterized by its ability to generate lesions in DNA through the formation of adducts with platinum, thereby inhibiting replication and transcription and leading to cell death. However, its use can lead to serious inconvenience arising from the development of resistance that some patients acquire during treatment, limiting the scope of its full potential. Currently, the biochemical mechanisms related to resistance are not precisely known. Therefore, knowledge of pathways associated with resistance caused by carboplatin exposure may provide valuable clues for more efficient rational drug design in platinum-based therapy and the development of new therapeutic strategies. In this narrative review, we discuss some of the known mechanisms of resistance to platinumbased drugs, especially carboplatin.
\end{abstract}

Uniterms: Carboplatin/mechanisms of resistance. Cisplatin/mechanisms of resistance. Drugs/resistance. Molecular targets. Antitumors/platinum-based.

\begin{abstract}
A carboplatina é um derivado da cisplatina, possuindo mecanismo de ação similar, diferindo em estrutura e toxicidade. Este fármaco foi aprovado pelo FDA em meados de 1980 e, desde então, tem sido amplamente usado no tratamento de diversos tipos de tumores. Este agente é caracterizado por sua habilidade em gerar lesões no DNA através da formação de adutos com a platina, inibindo a replicação e a transcrição, levando à morte celular. Entretanto, seu uso pode levar a graves inconvenientes, advindos do desenvolvimento de resistência que alguns pacientes adquirem durante o tratamento, limitando o alcance de seu potencial. Até então, os mecanismos bioquímicos relacionados ao problema da resistência não são precisamente conhecidos. Dessa forma, o conhecimento das vias associadas à resistência causada pela exposição à carboplatina pode prover valiosas informações para o planejamento racional de fármacos com base em platina mais eficiente e para o desenvolvimento de novas estratégias terapêuticas. Nesta revisão narrativa, serão discutidos alguns mecanismos de resistência a fármacos com base em platina, especialmente ao antitumoral carboplatina.
\end{abstract}

Unitermos: Carboplatina/mecanismos de resistência. Cisplatina/mecanismos de resistência. Fármacos/ resistência. Alvos moleculares. Antitumorais/baseados em platina.

\section{INTRODUCTION}

Carboplatin is a derivative of cisplatin and has a similar mechanism of action, differing only in terms of structure and toxicity. The anticancer activity of cisplatin

\footnotetext{
*Correspondence: G. Monteiro. Departamento de Tecnologia BioquímicoFarmacêutica, Faculdade de Ciências Farmacêuticas, Universidade de São Paulo. Av. Lineu Prestes, 580, Bloco 16 - Semi Industrial, $1^{\circ}$. andar, sala 135, Cidade Universitária Armando Salles de Oliveira, 05508-000 - São Paulo-SP, Brasil. E-mail: smgisele@usp.br
}

was discovered in the early 1960s by Professor Barnett Rosenberg at the University of Michigan (Rosenberg, Vancamp, Krigas, 1965; Rosenberg et al., 1969). He was interested in studying the effects of electric fields on bacterial growth, by establishing their involvement in the process of cell division. It was noted that after applying an electric field through a set of platinum electrodes immersed in a solution containing Escherichia coli, the cells not divided in a normal manner, and demonstrated filamentous growth of up to 300 times above normal 
(Rosenberg, Vancamp, 1970). This effect was found to be unrelated to the electric field, but related to the products of electrolysis of the platinum electrodes. Subsequent detailed chemical analysis identified several platinum complexes which induce this behavior, and that while the bivalent complex cis-[Pt $\left.\left(\mathrm{NH}_{3}\right)_{2} \mathrm{Cl}_{2}\right]$ was active, the trans isomer was much less active (Rosenberg, Vancamp, Krigas, 1965; Jamieson, Lippard, 1999).

After testing bacteria, Rosenberg started working on the possibility of using cisplatin in cancer treatment due to its anti-proliferative ability. Initial tests were performed on mice with malignant tumors, such as Kaposi 180. After the application of appropriate amounts of cisplatin, it was found that the drug was an effective antitumor agent, but at higher doses, cisplatin produced side effects such as kidney damage, discomfort, dizziness, nausea, and vomiting (Carozzi et al., 2009). According to Choudhary, Sood and Wang (2013), this drug has been proven to be effective for medical use in the treatment of several human cancers, including testis, ovary, brain, bladder, and lung.

After the pioneering work of Rosenberg, a huge number of metal complexes were studied, most of which were platinum-based. Since 1979, 1,055 platinum compounds have been tested, of which 185 were active. Considerable research worldwide has been triggered and more than 3,000 analogous compounds have been synthesized. Some of these new compounds are less toxic than cisplatin, but only five other compounds have been approved for commercialization: oxaliplatin, nedaplatin, lobaplatin, heptaplatin (the marketing of latter three is restricted to Japan, China and Korea, respectively), and carboplatin (McWhinney, Goldberg, McLeod, 2009; Wheate et al., 2010).

Carboplatin (1,1-cyclobutyldicarboxylate) is one of the main platinum-based drug used as an antitumor drug. It is intended specifically for the treatment of cancer of the testis, ovary, head, neck, and small cell lung cancer (Fuertes, Alonso, Perez, 2003). The main target of carboplatin is DNA, to which it binds efficiently, thereby inhibiting replication and transcription and inducing cell death (Brabec, Kasparkova, 2005). The nature of these DNA adducts affects a number of transduction pathways and triggers apoptosis or necrosis in tumor cells. The adducts formed by this compound can be monoadducts or intra and interchain diadducts (Hah et al., 2006) (Figure 1).

The development of resistance to platinum-based chemotherapy is a major clinical challenge in cancer treatment, since the cellular response which confers resistance to carboplatin is multifactorial and poorly understood (Wernyj, Morin, 2004; Shahzad, Berestein, Sood, 2009). It has been observed that the intracellular mechanisms by which cells become resistant to carboplatin include increased drug detoxification by the thiol groups in metallothionein and glutathione, repair, and improved tolerance to nuclear damage, leading to a concomitant reduction in apoptosis and reduced accumulation of intracellular carboplatin (Wang, Lippard, 2005; Stewart, 2007). Thus, inducing greater damage to DNA, impairing mechanisms of DNA repair, or activating and preventing apoptosis may lead to decreased tumor cell viability and could overcome resistance (Shahzad, Berestein, Sood, 2009; Burger et al., 2011).

Because of the low toxicity of carboplatin in clinical treatment, its association with other antitumor drugs has been tested in different types of cancer. Table I shows some of these associations and clinical outcomes in order to examine whether the combination therapy is favorable or not to the patient and which types of tumors (Kang et al., 2006; Honing et al., 2014; Chang et al., 2014; Angioli et al., 2013; Strauss et al., 2008;

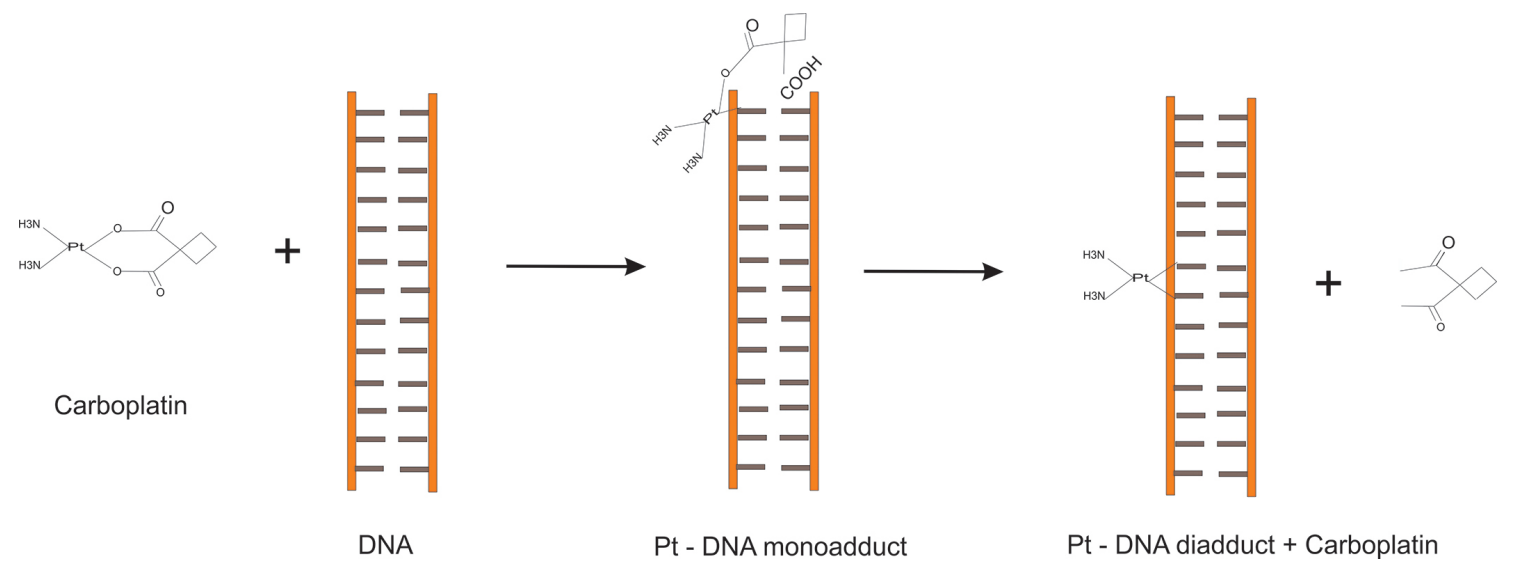

FIGURE 1 - Formation of adducts between DNA and carboplatin. 
TABLE I - Combination therapy with carboplatin

\begin{tabular}{|c|c|c|c|c|}
\hline Combination therapy & Dosage & Tumor & Favorable & References \\
\hline Carboplatin/Paclitaxel & AUC 5 e $175 \mathrm{mg} / \mathrm{m}^{2}$ & $\begin{array}{c}\text { Epithelial Ovarian } \\
\text { Cancer }\end{array}$ & Yes & Kang et al. (2006) \\
\hline Carboplatin/Paclitaxel & AUC 2 e $50 \mathrm{mg} / \mathrm{m}^{2}$ & Cancer of Esophagus & Yes & Honing et al.(2014) \\
\hline Carboplatin/Paclitaxel & AUC 5,5 e $175 \mathrm{mg} / \mathrm{m}^{2}$ & Lung Cancer & $\begin{array}{l}\text { Yes, in stage IB patients who } \\
\text { have tumors } \geq 4.0 \mathrm{~cm}\end{array}$ & Chang et al. (2014) \\
\hline Carboplatin/Paclitaxel & AUC 6 e $175 \mathrm{mg} / \mathrm{m}^{2}$ & Cancer of the Cervix & Yes & Angioli et al. (2013) \\
\hline Carboplatin/Paclitaxel & AUC 6 e $200 \mathrm{mg} / \mathrm{m}^{2}$ & Lung Cancer & $\begin{array}{l}\text { Yes, in stage IB patients who } \\
\text { have tumors } \geq 4.0 \mathrm{~cm}\end{array}$ & Strauss et al.(2008) \\
\hline Carboplatin/Paclitaxel & AUC 1 e $40 \mathrm{mg} / \mathrm{m}^{2}$ & $\begin{array}{c}\text { Cancer of the head and } \\
\text { neck }\end{array}$ & Yes & Semrau et al. (2011) \\
\hline Carboplatin/Docetaxel & AUC 6 e $60 \mathrm{mg} / \mathrm{m}^{2}$ & Cancer of the Cervix & No & Ukita et al.(2013) \\
\hline Carboplatin/Docetaxel & AUC 6 e $75 \mathrm{mg} / \mathrm{m}^{2}$ & Breast Cancer & $\begin{array}{l}\text { Yes, in patients with } \\
\text { metastatic breast cancer }\end{array}$ & Perez et al.(2005) \\
\hline Carboplatin/Docetaxel & AUC 5,5 e $75 \mathrm{mg} / \mathrm{m}^{2}$ & Lung Cancer & Yes & Zhi et al.(2013) \\
\hline Carbopltin/Gemcitabine & AUC 5 e $1000 \mathrm{mg} / \mathrm{m}^{2}$ & Lung Cancer & Yes & Lim et al. (2013) \\
\hline Carboplatin/Pemetrexed & AUC 5 e $500 \mathrm{mg} / \mathrm{m}^{2}$ & Lung Cancer & Yes & Pereira et al.(2011) \\
\hline $\begin{array}{l}\text { Carboplatin/Paclitaxel + } \\
\text { Bevacizumab }\end{array}$ & $\begin{array}{c}\text { AUC } 6,200 \mathrm{mg} / \mathrm{m}^{2} \mathrm{e} \\
15 \mathrm{mg} / \mathrm{kg}\end{array}$ & Lung Cancer & Yes & Twelves et al. (2014) \\
\hline Carboplatin/Vinorelbine & AUC 2,5 e $25 \mathrm{mg} / \mathrm{m}^{2}$ & Lung Cancer & Yes & Masters et al. (2003) \\
\hline
\end{tabular}

AUC, area under the concentration-time curve

Semrau et al., 2011; Ukita et al., 2013; Perez et al., 2005; Zhi et al., 2013; Lim, Li, Song, 2013; Pereira et al., 2011; Twelves et al., 2014; Masters et al., 2003).

The aim of this narrative review was to discuss some of the known molecular mechanisms involved in the absorption, metabolism, detoxification, and resistance to platinum-based drugs, especially carboplatin.

\section{MECHANISM OF ACTION}

To be activated, carboplatin must cross the cell membrane. Inside the cell, the molecule undergoes hydrolysis of 1,1-cyclobutanedicarboxylate, becoming positively charged. This allows carboplatin to interact with nucleophilic molecules (Figure 2) within the cell, including DNA, RNA and protein, generating the formation of adducts of platinum (McWhinney, Goldberg, McLeod, 2009). This process occurs through covalent binding of carboplatin to the N7 site of purine bases, forming DNA-protein or DNA-DNA interactions (Eastman, 1987; Amptoulach, Tsavaris, 2011).

Due to the pharmacodynamics of carboplatin, it has fewer side effects than its precursor cisplatin, although less potency, which might be due to differences in rates of adduct formation with DNA. These toxicity differences

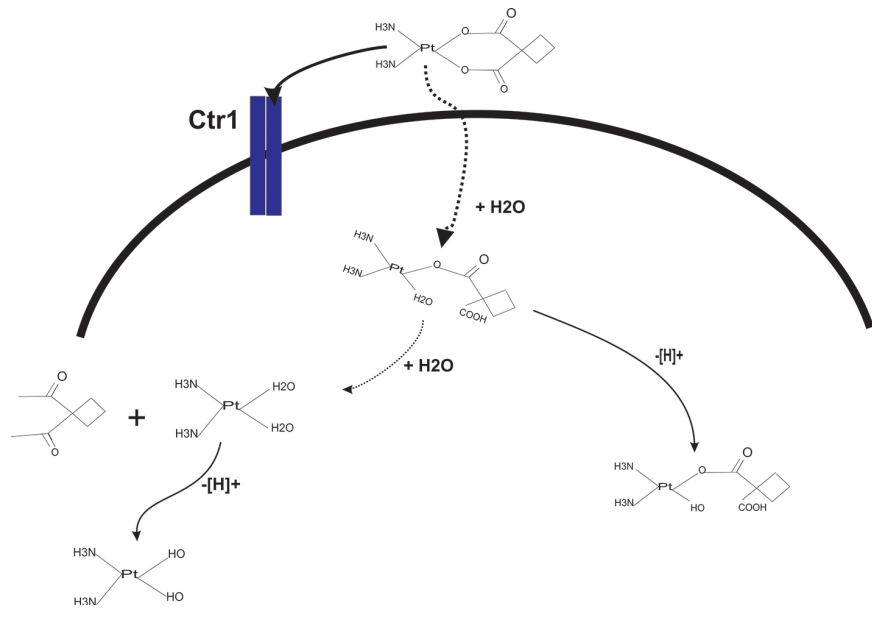

FIGURE 2 - Hydrolysis of carboplatin inside the cell. Ctr1 is the high affinity copper transporter (further described in Figure 4).

are probably due to the low reactivity rate of carboplatin with nucleophiles, since 1,1-cyclobutanedicarboxylate is a poorer leaving group than chloride (Figure 3) (Hah et al., 2006).

The linkage between DNA and carboplatin can produce lesions in DNA. Crosslinking between strands of DNA (interstrand cross-linking; ISC) is the most cytotoxic effect, because it inhibits the process of DNA replication, 


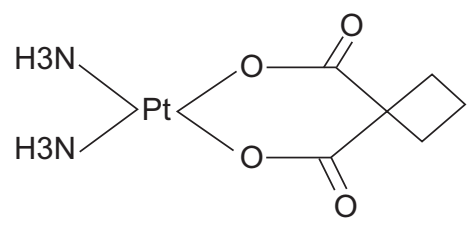

Carboplatin

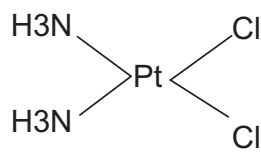

Cisplatin
FIGURE 3 - Molecular structure of platinum-based drugs. The respective leaving groups are highlighted.

causing changes that generate errors in replication, with the accumulation of cells in G2/M phase and the induction of apoptosis (Shi et al., 1994)1994. Alkylation of a single strand of DNA can be repaired easily, but cross-linked inter strands such as those produced by bifunctional alkylating agents require more complex mechanisms of repair (Rabik, Dolan, 2007).

Inside the cell, recognition of the damage caused by platinum occurs through the repair machinery. In the context of chromatin, the repair system may require exposure of the damaged double-stranded DNA outwards from the nucleosome, which is the fundamental building block of chromatin. It is the configuration of the DNA rotation on the surface of histone octamer which defines nucleotides that are directed into the solvent and which are occluded by histones (Kornberg, Lorch, 1999). Therefore, determining the connections between platinum in the DNA are located within the nucleosome is an important step in understanding the process of cell recognition. A key question is whether the adduct of platinum or the DNA sequence determines the configuration of the rotation of a DNA segment into the nucleosome and therefore how the platinum lesion is presented to the replication machinery, thereby affecting transcription and repair of the cell (Danford et al., 2005).

The system of DNA mismatch repair (MMR) is an important mechanism of replication which avoids errors caused by mutations (Fink et al., 1996). MMR is based on the recognition of DNA distortion caused by the presence of 6-thioguanine and adducts produced by carboplatin, generating an injury signal which might contribute to the initiation of apoptosis. This mechanism suggests that MMR proteins serve to detect DNA damage caused by these agents (Rabik, Dolan, 2007). Therefore, the loss of this repair mechanism can cause carboplatin resistance due to the inability to recognize the complex formed by DNA adducts with platinum drugs (Fink et al., 1996). Some studies have provided evidence that the loss of MMR proteins is associated with drug resistance in ovarian tumors. Additionally, methylation in the MLH1 promoter (the regulatory part of one MMR gene) performs an important role in the resistance to cisplatin in ovarian cancer cells grown in vitro (Zeller et al., 2012; Xiao, Melton, Gourley, 2014). Nucleotide excision repair (NER) is highly conserved and plays a key role in mediating resistance to drugs based on platinum (Rabik, Dolan, 2007). Injuries that result in changes to the helical structure of DNA and interfere with the mechanism of replication and transcription are repaired by this route. One important protein in the repair pathway of nucleotide excision repair is cross-complementation group 1 (ERCC1), which is postulated to play an important role in the efficacy of the drug (McWhinney, Goldberg, McLeod, 2009).

The repair of caudate adducts by platinum agents mainly occurs through the NER pathway. Although all three types of intra-strand crosslinks (1,2-d (ApG), 1.2-d (GPG) and d-1.3 (GpNpG)) are recognized by the NER mechanism, the first two intra-chain crosslinks are repaired less efficiently than 1.3 intra-chain crosslinks, supporting the hypothesis that 1.2 intra-strand crosslinks in DNA cause cytotoxic lesions (Rabik, Dolan, 2007). Two important molecules involved in the synthesis and damage repair of DNA, ERCC1 and RRM1, have been associated with the efficacy of treatment with platinumbased drugs. According to the work of Selvakumaran et al. (2003), ovarian cancer cell lines known to be resistant to platinum compounds show increased sensitivity after the silencing of ERCC1 protein expression using RNA interference, thereby demonstrating the association between NER and the clinical outcome of chemotherapy. Furthermore, studies evaluating the mRNA levels of ERCC1 in tumors from patients in clinical trials of nonsmall cell lung (Lord et al., 2002), colorectal (Shirota et al., 2001), and ovarian cancers (Kang et al., 2006) also showed an inverse association with survival or response to platinum compounds (Reynolds et al., 2009; Bowden, 2014; Moxley et al., 2013; Vilmar, Sørensen, 2009). Lower $E R C C 1$ expression, evaluated based on mRNA expression or protein levels, is related to better outcomes in several cancers after platinum-based treatment (De Castro et al., 2011). Da Costa Miranda et al. (2014) evaluated the prognostic and predictive role of the immunohistochemical expression of ERCC1 on the tumor response in patients with advanced biliary tract cancer. According to these authors, this expression was not either predictive or prognotic. However, the authors cite some drawbacks of the study, as the sample group was small and the study was conducted in a single center in Brazil. The manner whereby platinum drugs enter cells has traditionally been attributed to simple passive diffusion. However, some studies suggest that a number of mechanisms of uptake and efflux are active in the process, 
and altered regulation of these transporters is responsible for the reduced accumulation of drugs in resistant cells (Hall et al., 2008). Anticancer drugs based on platinum, such as cisplatin, oxaliplatin and carboplatin, are captured by cells, followed by binding to DNA and cytotoxicity (Wang, Lippard, 2005). Platinum uptake varies widely among different cell types and different types of tissues, and is a factor in the sensitivity and resistance of tumors (Liu et al., 2013).

Transporters of metals such as copper transporters, i.e. CTR1, ATP7A and ATP7B, have been of particular interest in the study of drugs based on platinum. A significant influence of the carrier CTR1 has been observed in mediating the influx of carboplatin, while ATP7B and ATP7A are known to be mediators of copper removal from the cell. ATP7A is expressed in the epithelium of the intestine and other tissues, except the liver, whereas ATP7B is expressed in liver, kidney, and to a lesser extent in the brain (Sprowl, Ness, Sparreboom, 2013). The ATP7B transporter, an ATP-binding cassette, sub-family C2 (ABCC2, also known as MRP2 or cMOAT) has been reported to be important in the efflux of carboplatin (Cui et al., 1999; Katano et al., 2003; Samimi et al., 2004b). The uptake and efflux of carboplatin are apparently linked to the metabolism of copper; this pathway leads to the hypothesis that copper and carboplatin can interfere with their mutual transport, thereby reducing the absorption of each other (Ohashi et al., 2003). One of the main efflux pathways associated with copper, and apparently also associated with carboplatin efflux, is the detoxification mechanism mediated by glutathione and metallothionein (Figure 4).

According to McWhinney, Goldberg and McLeod (2009), the exclusion of the CTR 1 gene in yeast results in a significant accumulation of three clinically available platinum analogs, including carboplatin. Forced overexpression of CTR1 in human ovarian cancer cells increases the absorption of platinum-based drugs, indicating that CTR 1 plays a key role in the cellular accumulation of these drugs.

Studies in patients with Menkes disease, or in patients that express neither ATP7A nor ATP7B, demonstrated greater accumulation of copper than cells transfected with vectors containing ATP7A or ATP7B (Samimi et al., 2004a), indicating that these carriers have higher levels of expression in platinum-resistant cells (Katano et al., 2003). Furthermore, high levels of ATP7A and ATP7B are associated with a poor response in patients with ovarian cancer receiving cisplatin or carboplatinbased chemotherapies (Martinez-Balibrea et al., 2009). Li et al. (2012) demonstrated that overexpression ATP7A

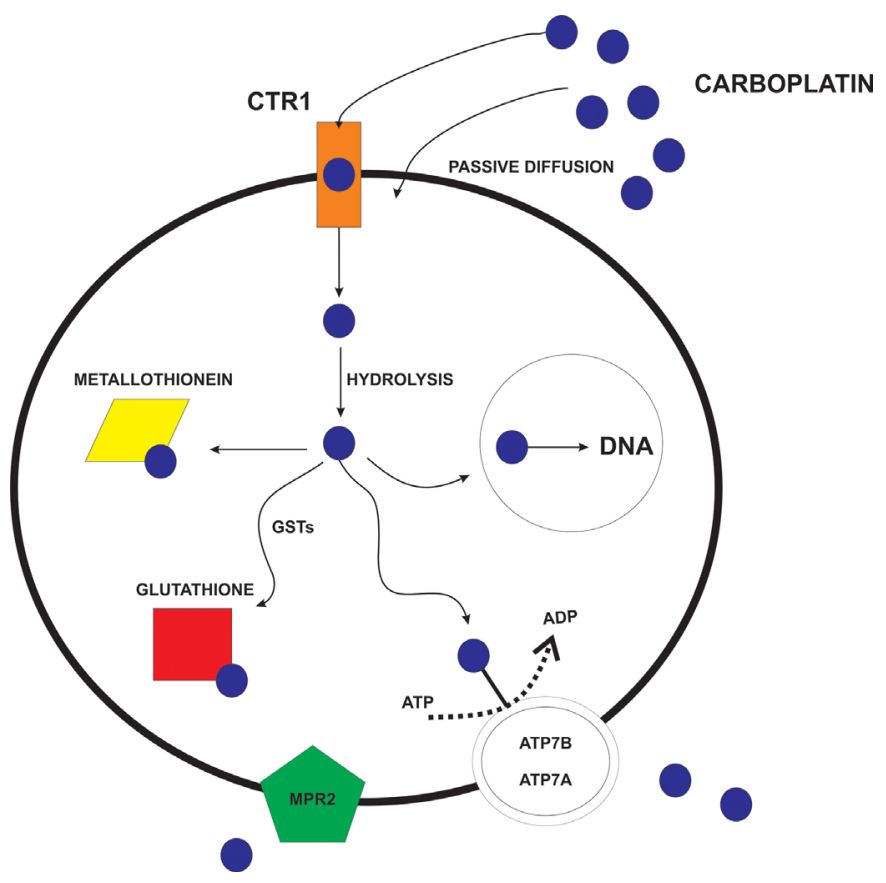

FIGURE 4 - Mechanism of detoxification of carboplatin within the cell.

in non-small cell lung cancer cells conferred resistance to platinum-based chemotherapy.

\section{CONCLUSION}

Resistance to carboplatin is a major problem in cancer therapy and has attracted the attention of researchers. Hopefully, further investigations will be carried out so that we can identify the causal mechanisms of resistance to carboplatin, allowing more effective use of this highly effective product. The DNA repair pathway increases cell resistance to carboplatin, and activation of the NER or MMR pathway in addition to the detoxification mechanisms of carboplatin (cytoplasmic mechanisms) are known to be involved in resistance. New observations have pointed to metal transporters as a mechanism of resistance to carboplatin, including the copper transporters CTR1, ATP7A and ATP7B. Determining the causative mechanism of resistance to platinum agents in tumors and reducing the toxic side effects of these drugs in patients will be beneficial to a large number of cancer patients who receive these drugs.

\section{ACKNOWLEDGMENTS}

We thank FAPESP (grants 2009/01303-1 and 2011/04173-1) and CAPES for financial support.

* The authors declare no conflicts of interest. 


\section{REFERENCES}

AMPTOULACH, S.; TSAVARIS, N. Neurotoxicity caused by the treatment with platinum analogues. Chemother. Res. Pract., v.2011, p.1-5, 2011.

ANGIOLI, R.; PLOTTI, F.; LUVERO, D.; ALOISI, A.; GUZZO, F.; CAPRIGLIONE, S.; TERRANOVA, C.; NARDONE, C.C.; PANICI, P.B. Feasibility and safety of carboplatin plus paclitaxel as neoadjuvant chemotherapy for locally advanced cervical cancer: a pilot study. Tumour Biol., v.35, p.2741-2746, 2013.

BOWDEN, N.A. Nucleotide excision repair: Why is it not used to predict response to platinum-based chemotherapy? Cancer Lett., v.346, p.163-171, 2014.

BRABEC, V.; KASPARKOVA, J. Modifications of DNA by platinum complexes. Relation to resistance of tumors to platinum antitumor drugs. Drug Resist. Updat., v.8, p.13146, 2005.

BURGER, H.; LOOS, W.J.; EECHOUTE, K.; VERWEIJ, J.; MATHIJSSEN, R.H.; WIEMER, E.A. Drug transporters of platinum-based anticancer agents and their clinical significance. Drug Resist. Updat., v.14, p.22-34, 2011.

CAROZZI, V.; CHIORAZZI, A.; CANTA, A.; OGGIONI, N.; GILARDINI, A.; RODRIGUEZ-MENENDEZ, V.; AVEZZA, F.; CRIPPA, L.; CERESA, C.; NICOLINI, G.; BOSSI, M.; CAVALETTI, G. Effect of the chronic combined administration of cisplatin and paclitaxel in a rat model of peripheral neurotoxicity. Eur. J. Cancer, v.45, p.656-665, 2009.

CHANG, W.J.; SUN, J.M.; LEE, J.Y.; AHN, J.S.; AHN, M.J.; PARK, K. A retrospective comparison of adjuvant chemotherapeutic regimens for non-small cell lung cancer (NSCLC): Paclitaxel plus carboplatin versus vinorelbine plus cisplatin. Lung Cancer, v.84, p.51-55, 2014.

CHOUDHARY, S.; SOOD, S.; WANG, H.C. Synergistic induction of cancer cell death and reduction of clonogenic resistance by cisplatin and FK228. Biochem. Biophys. Res. Commun., v.436, p.325-330, 2013.

CUI, Y.; KONIG, J.; BUCHHOLZ, J.K.; SPRING, H.; LEIER, I.; KEPPLER, D. Drug resistance and ATP-dependent conjugate transport mediated by the apical multidrug resistance protein, MRP2, permanently expressed in human and canine cells. Mol. Pharmacol., v.55, p.929-937, 1999.
DA COSTA MIRANDA, V.; BRAGHIROLI, M.I.; FARIA, L.D.; SIQUEIRA, S.A.; SABBAGA, J.; HOFF, P.M.; RIECHELMANN, R.P. ERCC1 in advanced biliary tract cancer patients treated with chemotherapy: prognostic and predictive roles. J. Gastrointest. Cancer, v.45, p.80-86, 2014.

DANFORD, A.J.; WANG, D.; WANG, Q.; TULLIUS, T.D.; LIPPARD, S.J. Platinum anticancer drug damage enforces a particular rotational setting of DNA in nucleosomes. Proc. Natl. Acad. Sci. USA, v.102, p.12311-12316, 2005.

DE CASTRO, G.JR.; PASINI, F.S.; SIQUEIRA, S.A.; FERRAZ, A.R.; VILLAR, R.C.; SNITCOVSKY, I.M.; FEDERICO, M.H. ERCC1 protein, mRNA expression and T19007C polymorphism as prognostic markers in head and neck squamous cell carcinoma patients treated with surgery and adjuvant cisplatin-based chemoradiation. Oncol. Rep., v.25, p.693-699, 2011.

EASTMAN, A. Cross-linking of glutathione to DNA by cancer chemotherapeutic platinum coordination complexes. Chem. Biol. Inter., v.61, p.241-248, 1987.

FINK, D.; NEBEL, S.; AEBI, S.; ZHENG, H.; CENNI, B.; NEHME, A.; CHRISTEN, R.D.; HOWELL, S.B. The role of DNA mismatch repair in platinum drug resistance. Cancer Res., v.56, p.4881-4886, 1996.

FUERTES, M.A.; ALONSO, C.; PEREZ, J.M. Biochemical modulation of cisplatin mechanisms of action: enhancement of antitumor activity and circumvention of drug resistance. Chem. Rev., v.103, p.645-662, 2003.

HAH, S.S.; STIVERS, K.M.; DE VERE WHITE, R.W.; HENDERSON, P.T. Kinetics of carboplatin-DNA binding in genomic DNA and bladder cancer cells as determined by accelerator mass spectrometry. Chem. Res. Toxicol., v.19, p.622-626, 2006.

HALL, M.D.; OKABE, M.; SHEN, D.W.; LIANG, X.J.; GOTTESMAN, M.M. The role of cellular accumulation in determining sensitivity to platinum-based chemotherapy. Annu. Rev. Pharmacol. Toxicol., v.48, p.495-535, 2008.

HONING, J.; SMIT, J.K.; MUIJS, C.T.; BURGERHOF, J.G.M.; DE GROOT, J.W.; PAARDEKOOPER, G.; MULLER, K.; WOUTERSEN, D.; LEGDEUR, M.J.C.; FIETS, W.E.; SLOT, A.; BEUKEMA, J.C.; PLUKKER, J.T.; HOSPERS, G.A. A comparison of carboplatin and paclitaxel with cisplatinum and 5-fluorouracil in definitive chemoradiation in esophageal cancer patients. Ann. Oncol., v.25, p.638-643, 2014. 
JAMIESON, E.R.; LIPPARD, S.J. Structure, recognition, and processing of cisplatin-DNA adducts. Chem. Rev., v.99, p.2467-2498, 1999.

KANG, S.; JU, W.; KIM, J.W.; PARK, N.H.; SONG, Y.S.; KIM, S.C.; PARK, S.Y.; KANG, S.B.; LEE, H.P. Association between excision repair cross-complementation group 1 polymorphism and clinical outcome of platinum-based chemotherapy in patients with epithelial ovarian cancer. Exp. Mol. Med., v.38, p.320-324, 2006.

KATANO, K.; SAFAEI, R.; SAMIMI, G.; HOLZER, A.; ROCHDI, M.; HOWELL, S.B. The copper export pump ATP7B modulates the cellular pharmacology of carboplatin in ovarian carcinoma cells. Mol. Pharmacol., v.64, p.466$473,2003$.

KORNBERG, R.D.; LORCH, Y. Chromatin-modifying and -remodeling complexes. Curr. Opin. Genet. Dev., v.9, p.148-151, 1999.

LI, Z.H.; QIU, M.Z.; ZENG, Z.L.; LUO, H.Y.; WU, W.J.; WANG, F.; WANG, Z.Q.; ZHANG, D.S.; LI, Y.H.; XU, R.H. Copper-transporting P-type adenosine triphosphatase (ATP7A) is associated with platinum resistance in non-small cell lung cancer (NSCLC). J. Transl. Med., v.10, p.10-21, 2012.

LIM, K.H.; LEE, H.Y.; SONG, S.Y. Efficacy and feasibility of gemcitabine and carboplatin as first-line chemotherapy in elderly patients with advanced non-small cell lung cancer. Chin. Med. J., v.126, p.4446-4448, 2013.

LIU, J.J.; KIM, Y.; YAN, F.; DING, Q.; IP, V.; JONG, N.N.; MERCER, J.F.; MCKEAGE, M.J. Contributions of rat Ctr1 to the uptake and toxicity of copper and platinum anticancer drugs in dorsal root ganglion neurons. Biochem. Pharmacol., v.85, p.207-215, 2013.

LORD, R.V.; BRABENDER, J.; GANDARA, D.; ALBEROLA, V.; CAMPS, C.; DOMINE, M.; CARDENAL, F.; SANCHEZ, J.M.; GUMERLOCK, P.H.; TARON, M.; SANCHEZ, J.J.; DANENBERG, K.D.; DANENBERG, P.V.; ROSELL, R. Low ERCC1 expression correlates with prolonged survival after cisplatin plus gemcitabine chemotherapy in non-small cell lung cancer. Clin. Cancer Res., v.8, p.2286-2291, 2002.
MARTINEZ-BALIBREA, E.; MARTÍNEZ-CARDÚS, A.; MUSULÉN, E.; GINÉS, A.; MANZANO, J.L.; ARANDA, E.; PLASENCIA, C.; NEAMATI, N.; ABAD, A. Increased levels of copper efflux transporter ATP7B are associated with poor outcome in colorectal cancer patients receiving oxaliplatin-based chemotherapy. Int. J. Cancer, v.124, p.2905-2910, 2009.

MASTERS, G.A.; HAHN, E.A.; SHEVRIN, D.H.; KIES, M.S. Phase I/II trial of vinorelbine and divided-dose carboplatin in advanced non-small cell lung cancer. Lung Cancer, v.39, p.221-226, 2003.

MCWHINNEY, S.R.; GOLDBERG, R.M.; MCLEOD, H.L. Platinum neurotoxicity pharmacogenetics. Mol. Cancer Ther., v.8, p.10-16, 2009.

MOXLEY, K.M.; BENBROOK, D.M.; QUEIMADO, L.; ZUNA, R.E.; THOMPSON, D.; MCCUMBER, M.; PREMKUMAR, P.; THAVATHIRU, E.; HINES, L.; MOORE, K.N. The role of single nucleotide polymorphisms of the ERCC1 and MMS19 genes in predicting platinumsensitivity, progression-free and overall survival in advanced epithelial ovarian cancer. Gynecol. Oncol., v.130, p.377-382, 2013.

OHASHI, K.; KAJIYA, K.; INABA, S.; HASEGAWA, T.; SEKO, Y.; FURUCHI, T.; NAGANUMA, A. Copper(II) protects yeast against the toxicity of cisplatin independently of the induction of metallothionein and the inhibition of platinum uptake. Biochem. Biophys. Res. Commun., v.310, p.148-152, 2003.

PEREIRA, J.R.; KIM, J.H.; MAGALLANES, M.; LEE, D.H.; WANG, J.; GANJU, V.; BARRERA, L.M.; BARRACLOUGH, H.; KOOTEN, M.V.; ORLANDO, M. A Randomized phase 3 trial comparing pemetrexed/ carboplatin and docetaxel/carboplatin as first-line treatment for advanced, nonsquamous non-small cell lung cancer. $J$. Thorac. Oncol., v.6, p.1907-1914, 2011.

PEREZ, E.A.; SUMAN, V.J.; FITCH, T.R.; MAILLIARD, J.A.; INGLE, J.N.; COLE, J.T.; VEEDER, M.H.; FLYNN, P.J.; WALSH, D.J.; ADDO, F.K. A phase II trial of docetaxel and carboplatin as first-line chemotherapy for metastatic breast cancer: NCCTG Study N9932. Oncology, v.69, p.117-121, 2005.

RABIK, C.A.; DOLAN, M.E. Molecular mechanisms of resistance and toxicity associated with platinating agents. Cancer Treat. Rev., v.33, p.9-23, 2007. 
REYNOLDS, C.; OBASAJU, C.; SCHELL, M.J.; LI, X.; ZHENG, Z.; BOULWARE, D.; CATON, J.R.; DEMARCO, L.C.; O'ROURKE, M.A.; WRIGHT, G.S.; BOEHM, K.A.; ASMAR, L.; BROMUND, J.; PENG, G.; MONBERG, M.J.; BEPLER, G. Randomized phase III trial of gemcitabine-based chemotherapy with in situ RRM1 and ERCC1 protein levels for response prediction in non-smallcell lung cancer. J. Clin. Oncol., v.27, p.5808-5815, 2009.

ROSENBERG, B.; VANCAMP, L. The successful regression of large solid sarcoma 180 tumors by platinum compounds. Cancer Res., v.30, p.1799-1802, 1970.

ROSENBERG, B.; VANCAMP, L.; KRIGAS, T. Inhibition of cell division in Escherichia coli by electrolysis products from a platinum electrode. Nature, v.205, p.698-699, 1965.

ROSENBERG, B.; VANCAMP, L.; TROSKO, J.E.; MANSOUR, V.H. Platinum compounds: a new class of potent antitumour agents. Nature, v.222, p.385-386, 1969.

SAMIMI, G.; KATANO, K.; HOLZER, A.K.; SAFAEI, R.; HOWELL, S.B. Modulation of the cellular pharmacology of cisplatin and its analogs by the copper exporters ATP7A and ATP7B. Mol. Pharmacol., v.66, p.25-32, 2004 a.

SAMIMI, G.; SAFAEI, R.; KATANO, K.; HOLZER, A.K.; ROCHDI, M.; TOMIOKA, M.; GOODMAN, M.; HOWELL, S.B. Increased expression of the copper efflux transporter ATP7A mediates resistance to cisplatin, carboplatin, and oxaliplatin in ovarian cancer cells. Clin. Cancer Res., v.10, p.4661-4669, 2004b.

SELVAKUMARAN, M.; PISARCIK, D.A.; BAO, R.; YEUNG, A.T.; HAMILTON, T.C. Enhanced cisplatin cytotoxicity by disturbing the nucleotide excision repair pathway in ovarian cancer cell lines. Cancer Res., v.63, p.1311-1316, 2003.

SEMRAU, R.; TEMMING, S.; PREUSS, S.F.; KLUBMANN, J.P.; GUNTINAS-LICHIUS, O.; MÜLLER, R.P. Definitive radiochemotherapy of advanced head and neck cancer with carboplatin and paclitaxel. Strahlenther Onkol., v.187, p.645-650, 2011.

SHAHZAD, M.M.K.; BERESTEIN, G.L.; SOOD, A.K. Novel strategies for reversing platinum resistance. Drug Resist. Updat., v.12, p.148-152, 2009.
SHI, L.; NISHIOKA, W.K.; TH'NG, J.; BRADBURY, E.M.; LITCHFIELD, D.W.; GREENBERG, A.H. Premature p34cdc2 activation required for apoptosis. Science, v.263, p.1143-1145, 1994.

SHIROTA, Y.; STOEHLMACHER, J.; BRABENDER, J.; XIONG, Y.P.; UETAKE, H.; DANENBERG, K.D.; GROSHEN, S.; TSAO-WEI, D.D.; DANENBERG, P.V.; LENZ, H.J. ERCC1 and thymidylate synthase mRNA levels predict survival for colorectal cancer patients receiving combination oxaliplatin and fluorouracil chemotherapy. $J$. Clin. Oncol., v.19, p.4298-4304, 2001.

SPROWL, J.A.; NESS, R.A.; SPARREBOOM, A. Polymorphic transporters and platinum pharmacodynamics. Drug Metab. Pharmacokinet., v.28, p.19-27, 2013.

STEWART, D.J. Mechanisms of resistance to cisplatin and carboplatin. Crit. Rev. Oncol. Hematol., v.63, p.12-31, 2007.

STRAUSS, G.M.; HERNDON, J.E. $2^{\text {nd }}$; MADDAUS, M.A.; JOHNSTONE, D.W.; JOHNSON, E.A.; HARPOLE, D.H.; GILLENWATER, H.H.; WATSON, D.M.; SUGARBAKER, D.J.; SCHILSKY, R.L.; VOKES, E.E.; GREEN, M.R. Adjuvant paclitaxel plus carboplatin compared with observation in stage IB non-small-cell lung cancer: CALGB 9633 with the Cancer and Leukemia Group B, Radiation Therapy Oncology Group, and North Central Cancer Treatment Group Study Groups. J. Clin. Oncol., v.26, p.5043-5051, 2008.

TWELVES, C.; CHMIELOWSKA, E.; HAVEL, L.; POPAT, S.; SWIEBODA-SADLEJ, A.; SAWRYCKI, P.; BYCOTT, P.; INGROSSO, A.; KIM, S.; WILLIAMS, J.A.; CHEN, C.; OLSZANSKI, A.J.; DE BESI, P.; SCHILLER, J.H. Randomised phase II study of axitinib or bevacizumab combined with paclitaxel/carboplatin as first-line therapy for patients with advanced non-small-cell lung cancer. Ann. Oncol., v.25, p.132-138, 2014

UKITA, Y.; TSUBAMOTO, H.; KATO, T.; SUNO, S.; SHIBAHARA, H. A case of primary metastatic glassy cell carcinoma of the uterine cervix that responded to combined docetaxel and carboplatin. Gynecol. Oncol. Rep., v.6, p.1921, 2013.

VILMAR, A.; SØRENSEN, J.B. Excision repair crosscomplementation group 1 (ERCC1) in platinum-based treatment of non-small cell lung cancer with special emphasis on carboplatin: a review of current literature. Lung Cancer, v.64, p.131-139, 2009. 
WANG, D.; LIPPARD, S.J. Cellular processing of platinum anticancer drugs. Nat. Rev. Drug Discov., v.4, p.307-320, 2005.

WERNYJ, R.P.; MORIN, P.J. Molecular mechanisms of platinum resistance: still searching for the Achilles' heel. Drug Resist. Updat., v.7, p.227-232, 2004.

WHEATE, N.J.; WALKER, S.; CRAIG, G.E.; OUN, R. The status of platinum anticancer drugs in the clinic and in clinical trials. Dalton Trans., v.39, p.8113-8127, 2010.

XIAO, X.; MELTON, D.W.; GOURLEY, C. Mismatch repair deficiency in ovarian cancer - Molecular characteristics and clinical implications. Gynecol. Oncol., v.132, p.506$512,2014$.
ZELLER, C.; DAI, W.; STEELE, N.L.; SIDDIQ, A.; WALLEY, A.J.; WILHELM-BENARTZI, C.S.M.; RIZZO, S.; VAN DER ZEE, A.; PLUMB, J.A.; BROWN, R. Candidate DNA methylation drivers of acquired cisplatin resistance in ovarian cancer identified by methylome and expression profiling. Oncogene, v.31, p.4567-4576, 2012.

ZHI, X.; GAO, W.; HAN, B.; YANG, Y.; LI, H.; LIU, D.; WANG, C.; MIN, G.; LONG, H.; RIGAS, J.R.; CAREY, M.; JAHAN, T.; SAMMANN, A.; REZA, J.; WANG, D.; MANN, M.J.; JABLONS, D.M.; HE, J. VATS lobectomy facilitates the delivery of adjuvant docetaxel-carboplatin chemotherapy in patients with non-small cell lung cancer. J. Thorac. Dis., v.5, p.578-584, 2013.

Received for publication on $20^{\text {th }}$ December 2013 Accepted for publication on $13^{\text {th }}$ March 2014 
